\title{
Research on New Methods of College Students' Ideological and Political Education in the Context of Marxism in China
}

\author{
Ying Ji \\ Oxbridge College, Kunming University of Science and Technology, \\ Kunming, Yunnan, 650000, China
}

\begin{abstract}
Marxism in China refers to the great theoretical results combining Chinese actual situation and the basic principles of Marxism and it is the embodiment of Marxism in China with its practical value and historical significance. It is very important for college students to do ideological and political education under the background of Marxism sinicization, it not only conductive to the healthy growth and development of university students, but also to the long-term stability of university construction in China and it is an important factor of comprehensive development in China. This article mainly analyzes the ideological and political education work of Chinese under the background of Marxism in China, and puts forward some new methods for how to scientifically carry out the ideological and political education of college students under the background of Marxism in China. Keywords: Marxism; sinicization; college students; ideological and political education
\end{abstract}

\section{Introduction}

For scientific socialism, Marxist theory is its basic road map, guiding the Communist Party of China and the people of all nationalities in the line of action and the theoretical program, but also in building a socialist well-off society in the process of always adhere to the important principles and theory. During the process of practicing Marxism in our country, the Communist Party of China unceasingly combined the construction and development of the Chinese 
revolution with the basic theory and basic principle of Marxism, and gradually formed a development concept with Chinese characteristics of socialism, which is Marxist Chinese Characteristics. At present, regardless of which stage of education in China, ideological and political education has been generally attached great importance to educators, how to make good use of the basic spirit of Marxism in China and the principle of ideological and political education in colleges and universities must focus on Taking into account the problems of Marxism in China to ideological and political education to bring the opportunity to take a reasonable approach to promote the overall political quality of college students and ideological level of progress for our construction and training with more high-quality useful talent.

\section{Emancipate mind, find the exact starting point for the ideological and political education for college students}

The close connection between the basic principles of Marxism and Chinese actual conditions is the core content of Marxism in China, which emphasizes the mutual influence between emancipating the mind, advancing with the times and seeking truth from facts. Since the new period, the ideological and political education environment has undergone great changes in China, and the educational objects have also changed. Therefore, it is necessary for colleges and universities to break through the traditional confinement and emancipate the mind and find the ideological and political education of college students. Specific practices are as follows:

\subsection{Make full use of network advantages, taking the network as an important form of ideological and political education for college students}

These traditional forms of information transmission and exchange have the great weakness, affecting the effective ideological and political education of college students. With the rapid development of network technology, China has gradually entered the era of network, making college students to accept information on the ways and means of a huge change, the campus network, Internet, blog, We-Chat and other contemporary students to become the main ideological exchange form. Therefore, ideological and political education for college students, it should be aware of this change in college students, the timely updating of educational concepts, the emergence of new forms of online education bold exploration, grasp the opportunity of online education, network education The role of full play to the ideological and political education in college students.

To develop the network into an important form of ideological and political education of college students, we should pay attention to the following three aspects: First, we must strengthen the study and application of modern information network technology, the Internet and campus network and other forms of network To make full use of ideological and political education for college students to open the corresponding ideological and political education 
column or page, to strengthen exchanges and interaction between teachers and students. Second, the freedom of the network dialogue, openness and virtual characteristics to be accurate, take a straightforward, flexible and diverse forms for college students to show the facts, so that students understand the facts contained in the various principles and Truth, but also respect the freedom of speech of students, giving students the space of individual development, so that it can be more active and pleasant to accept the ideological and political education. Finally, we must effectively combine the traditional way of education and emerging online education, interactive use, complement each other, together for the ideological and political education to contribute to college students.

\subsection{Make the effective combination of positive education and negative education to ensure the comprehensive and rational content of ideological and political education}

For the ideological and political education of college students, the effective combination of positive education and negative education is also an accurate starting point, dealing with the relationship between positive education and negative education can further guarantee the effectiveness of ideological and political education. For the ideological and political education of college students, positive education refers to the society is full of sunshine side of the education, ideological and political education workers should actively positive preaching for students, for the existence of problems to try to avoid. The negative education refers to the dark side of education in society, so that students look at the existence of various problems in society, the students against the appropriate warning, for sensitive issues not to be avoided. Positive education and negative education in the ideological and political education should occupy a reasonable proportion has always been related to educators to explore the issue. If we blindly educate the students and ignore the dark side of society, we can only tell the students to avoid the problems that exist in the society, which will only lead the students to lose the correct guidance. It is difficult to cope with the complicated social life. . Therefore, in the ideological and political education of university students, we should grasp the positive education and negative education between the intensity of negative education as a double-edged sword, the use of good can also be an effective supplement to positive education, ideological and political education more complete and comprehensive.

In the ideological and political education of college students, the combination of positive education and negative education should pay attention to the following two points. First of all, whether positive or negative education, must be based on facts as the sole basis, adhere to the fundamental principle of seeking truth from facts, with the sincere feelings to arouse the students' resonance. Second, we must also carry out positive and positive guidance can not stay in the negative disclosure of education in fact, to lead students to analyze the facts of science to guide students through the phenomenon to see the essence. 


\section{Adhere to the principle of seeking truth from facts, find the exact focus of ideological and political education for college students}

Seeking truth from facts is an important basic criterion in the localization of Marxism in China. It refers to doing everything according to objective reality and pursuing a practical effect. In the context of Marxism with Chinese characteristics, the innovation of ideological and political education of college students not only requires emancipating the mind, finding a suitable starting point for ideological and political education of college students, but also clear the focus of ideological and political education of college students, the pursuit of college students The Actual Effect of Ideological and Political Education. To this end should do the following three points:

\subsection{Put emphasis on the cultivation of professionalism for college students}

Colleges and universities not only assume the responsibility of training highquality students, more important is to teach the students through the correct college life, so that students get into the community before working hard to understand what is a truly qualified professional. Therefore, the ideological and political education in college students should pay attention to the cultivation of the professionalism of college students, from the road of life, life coordinates, life values and ideals of life and so on, in the ideological and political education to guide them to establish a correct view of the world, And values, so that they learn to correctly deal with personal interests and the interests of the body, the individual and society, the relationship between competition and collaboration.

\subsection{Put emphasis on the cultivation of the cooperation awareness and sense of responsibility for college students}

In the past, ideological and political education of college students found that many college students in China there is a lack of awareness of cooperation and awareness of the problem of responsibility. Therefore, colleges and universities should actively carry out professional ethics practice for college students, students in the daily learning and practice will be integrated into the practice of professional ethics, so that students develop good health and professional ethics. In particular, students should pay attention to the responsibility education and honesty education, so that students can practice the socialist concept of honour and disgrace, the application of the results of Marxism in China to practice life.

\subsection{Put emphasis on the comprehensive development of college students}

Effective ideological and political education for college students can provide more impetus for the all - round development of college students. For colleges and universities, it should focus on improving the overall quality of all students, including college students with professional quality, knowledge and physical and 
mental health. When carrying out the ideological and political education of college students, the students should be put into the social environment to consider the content of the ideological and political education from the students' actual development needs and the needs of social construction, and create a favourable environment for college students to achieve all-round development of the environment.

\section{Advancing with the times, find the right innovation of ideological and political education for college students}

Improving and perfecting the ideological and political education of college students is a process which needs long - term effort. The society is always changing. Only when we keep pace with the times can the ideological and political education of university students always meet the students' development needs and social construction needs. And the core content of Marxism in China also requires the ideological and political education to keep pace with the times, to reflect the ideological and political education of the regularity, times and creativity, followed by the trend of development of the times, combined with the ideological changes of college students Form, on the way of ideological and political education of university students to explore and expand.

\subsection{The practice training mechanism will be introduced to the ideological and political education in college students}

College students are a very active group of thinking, if we still adopt the dull and rigid theory of indoctrination teaching methods, will only lead to the ideological and political education of college students is more inefficient. Therefore, it is necessary to innovate the teaching model of ideological and political education for college students in time, introduce the training and practice mechanism, and continuously improve the infection rate and attractiveness of ideological and political education, thus promoting the ideological and political education to a deeper level. To combine the actual development needs of students and the specific content of teaching materials, the organization of students to practice the appropriate practical training activities, such as social research, red tourism, theme education, vocational simulation.

\subsection{Coordinate the relationship among EQ education, psychological education and professional quality education}

In the ideological and political education, emotional education, psychological education and professional quality education has always been an important supplement, which is the lack of emotional, psychological unhealthy, lack of professional quality and so on many college students, the coordination between the three The relationship between students can further enhance the effect of ideological and political education, emotional and psychological health of 
students to develop, but also can promote the formation of a scientific professional quality of students for the future learning and development of students to provide better conditions.

\section{Conclusion}

We can see that it is of great practical significance to improve and perfect the ideological and political education of college students in the context of Marxism in China, which is related to the overall level of development of Chinese college students, and therefore requires a new approach, Uphold the principle of emancipating the mind, seeking truth from facts and advancing with the times, to find the appropriate starting point, focus point and innovation point for the ideological and political education of college students, and promote the steady improvement of the efficiency and quality of the ideological and political education, so as to transport more personnel with high-quality and highly skill for Chinese national construction.

\section{References}

[1] Wang Handing. Most Reinvention of Marxist Beliefs: Possible Paths for Deepening Party Building among College Students - Also on Strengthening and Improving College Students' Ideological and Political Education with Party Construction as the Leading Role. Journal of Jingmen Polytechnic College, 55(10), pp.27-31, 2008

[2] On the Popularization of Marxism in Colleges and Universities Based on the Viewpoint of Strengthening Ideological and Political Education; Journal of Higher Correspondence Education (Philosophy and Social Sciences), 8(5), pp.7072,2010

[3] Li Weihong .Under the Guidance of the Scientific Outlook on Development, Deepening the Innovation and Development of Ideological and Political Education in Institutions of Higher Learning - A Speech at the Forum on the Innovation and Development of Moral Education in the 60th Anniversary of the Founding of New China, Journal of Ideological \& Theoretical Education, 12(10), pp. 18- 20, 2009

[4] Cheng Meidong. Study on Subjective Consciousness, Era Consciousness and Problem Consciousness: Practice and Innovation Basic Orientation of Marxism A Historical Survey of the Process of Marxism in China during the War of Resistance Against Japan. Marxist Studies, Study of Marxism, 9(6), pp.58- 61, 2011

[5] On the Development of Socialism Core Value System and the Theoretical System of Socialism with Chinese Characteristics. Guangxi Social Sciences, 8(12), pp.17-20, 2012 